\title{
Factors Affecting Stress and Job Satisfaction its Impact on Performance of Medical Representatives at Central Kerala Region with Special Reference to Era of Coronavirus (COVID-19) -Pandemic Outbreak.
}

\author{
Gayathri. T. J, E. Muthu Kumar
}

\begin{abstract}
This study is to find out and analyse the factors influencing job stress and job satisfaction and its impact on performance of Medical Representatives working under pharmaceutical industry, at Central Kerala districts (PALAKKAD, THRISSUR, ERNAKULAM and IDUKKI). We all know that increased stress leads to reduced productivity and also overall affects the overall performance. Stress is a universal phenomenon and common challenge to employee productivity, it is the unavoidable reality of modern day workplace. Apart from other professions, Medical Representative's daily life or work involves continuous field work, continuous travelling, waiting for Dr visits, administrative work, sales pressure, and more.. Medical Representatives need to be always physically fit, mentally alert \& attentive, presentable, punctual, patient, committed, responsive, skilled communicator, and an extrovert person to be able to succeed in the amazing competitive field of Pharmaceutical industry.
\end{abstract}

Keywords:-Pharmaceutical industry, Medical Representative, Job stress, performance, Job Satisfaction.

\section{INTRODUCTION}

$\mathrm{M}$ edical sales representatives or pharmaceutical company representatives are salesmen responsible for promoting pharmaceutical products to physician of different specialties, and thereby increases the sales of the company. No doubt, a medical representative's job is too challenging to put up for sale their company's products mainly pharmaceutical drugs. Customers can include doctors, nurses and pharmacists. Parellel to other sectors, pharmaceutical businesses also faced several problems whereby MR faced the most due to strict social distancing measures and individual concerns. Early 2020 the spread of the COVID-19 virus has changed the work of Medical Representatives. It is difficult to see a physician face to face, convincing, asking or begging him to prescribe a specific product to his patients. Field -visits had to be cancelled and the field -force was condemned to work from home, using their very untypical home-office.

Manuscript received on September 14, 2021

Revised Manuscript received on September 20, 2021.

Manuscript published on September 30, 2021.

* Correspondence Author

Gayathri.T.J*, M.B.A, M.Phil, Ph.D Scholar, Nehru College of Management Thirumalayampalayam, E-mail:- gayuajith333@gmail.com

Dr. E. Muthukumar, M.B.A, M. Phil, Ph.D Associate Professor Nehru college of Management Thirumalayampalayam Email:mkumar.mgt@gmail.com

(c) The Authors. Published by Blue Eyes Intelligence Engineering and Sciences Publication (BEIESP). This is an open access article under the CC BY-NC-ND license (http://creativecommons.org/licenses/by-nc-nd/4.0/)

\section{II.REVIEW OF LITERATURE}

Starc, J. (2018):-This study focussed to determine the basic causes of stress and examine the symptoms of stress among healthcare professionals at the primary and secondary level of health care. The survey results have shown that those employed in nursing are exposed to stressful situations on a daily basis, most often involving psychological or physical violence in the workplace, dealing with death, lack of personnel and a high frequency of patients. Naoko Nishitani et al. (2010):- In this present study, insomnia was associated with psychological job stress factors of appropriateness of work and qualitative workload. Workers with poor sleep or less sleep quality and insomnia reportedly have low interest or satisfaction in their work. Thus, a close relationship is shown between insomnia, job satisfaction and job difficulty, leading to impaired job performance. Kang (2005): The study identified interference of job in personal life, unsupportive colleagues, work overload and continuous pressure for improved performance were found causing stress among the medical representatives. While, performance inhibitors, effort reward imbalance, discourteous behaviour of clients and colleagues, lack of participation and politics in decision making, insufficient inputs, lack of empowerment, conflicting demands from the superior and inadequate incentives were found to be not associated with stress among them.

\section{III.OBJECTIVES OF THE STUDY}

- To analyse the relation between stress, satisfaction and performance of medical representatives.

- To analyse the variables which influences or impacts the performance of Medical Representatives.

- To suggest suitable measures to overcome stress and to enhance job satisfaction and performance of medical representatives.

\section{IV.RESEARCH HYPOTHESIS}

Ho1:-There is no significant relationship between the job stress and job satisfaction.

Ho2:-There is no significant relationship between stress and performance of Medical Representatives.

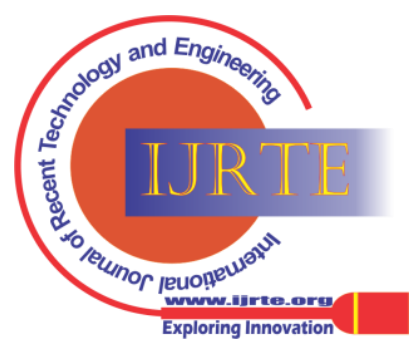


Factors Affecting Stress and Job Satisfaction its Impact on Performance of Medical Representatives at Central Kerala Region with Special Reference to Era of Coronavirus (COVID-19) -Pandemic Outbreak.

\section{V.RESEARCH DESIGN}

Research design used is Descriptive analysis and Research approach is quantitative in nature. Sample population is taken as Medical Representatives. Sample Design is Central zone of Kerala districts i.e., Palakkad, Thrissur, Ernakulam and Idukki. It covers total 750 tentative samples, out of which 727 have responded properly. Convenient sampling technique is adopted.

Primary Data:- The main tools for collecting primary data are through questionnaires and through interviews.

Secondary Data:- It is collected through various journals, publication of research agencies, magazines, newspaper, internet and libraries.

\section{VI.TOOLS FOR ANALYSIS}

Primary data collected from the respondents are edited and coded and also referred secondary data. The statistical analysis of data is done using SPSS. The main tools used are simple percentage analysis and Cross tabulation with Chisquare, Co-relation, Multiple Regression Method ,Structural Equation Modelling with AMOS.

Table showing the impact of Stress Level of Medical Representatives on their performance in kerala

Table 1.1 - Impact Of Stress Level Of Medical Representatives On Their Performance In Kerala ANOVATABLE

\begin{tabular}{|l|l|l|l|l|l|l|}
\hline \multicolumn{2}{|l|}{ Model } & $\begin{array}{l}\text { Sum } \\
\text { Squares }\end{array}$ & $\begin{array}{l}\text { Dean } \\
\text { Square }\end{array}$ & F & Sig. \\
\hline \multirow{3}{*}{1} & $\begin{array}{l}\text { Regressi } \\
\text { on }\end{array}$ & 404.683 & 13 & 31.129 & $\begin{array}{l}191.36 \\
.000\end{array}$ & \\
\cline { 2 - 8 } & Residual & 115.985 & 713 & 0.163 & & \\
\cline { 2 - 7 } & Total & 520.669 & 726 & & & \\
\hline
\end{tabular}

From the above ANOVA Table it can be confirmed that the influences of all independent variables on medical representative's support is significant. Since the sig value is 0.000 which is less than the accepted value 0.05 .

\begin{tabular}{|c|c|c|c|c|c|c|}
\hline \multicolumn{7}{|c|}{ COEFFICIENTS } \\
\hline & \multirow{2}{*}{ Model } & \multicolumn{2}{|c|}{$\begin{array}{c}\text { Unstandardized } \\
\text { Coefficients }\end{array}$} & \multirow{2}{*}{$\begin{array}{c}\text { Standardiz } \\
\text { ed } \\
\text { Coefficient } \\
\text { s } \\
\text { Beta }\end{array}$} & \multirow{2}{*}{$\mathbf{T}$} & \multirow{2}{*}{ Sig. } \\
\hline & & B & $\begin{array}{l}\text { Std. } \\
\text { Error }\end{array}$ & & & \\
\hline \multirow{7}{*}{1} & $\begin{array}{l}\text { (Constan } \\
\text { t) }\end{array}$ & 6.790 & .268 & & $\begin{array}{r}25.36 \\
2\end{array}$ & .000 \\
\hline & s1 & -.052 & .021 & -.097 & -2.425 & .016 \\
\hline & s2 & -.306 & .039 & -.325 & -7.831 & .000 \\
\hline & s3 & .126 & .020 & .237 & 6.271 & .000 \\
\hline & s4 & -.367 & .031 & -.705 & 11.73 & .000 \\
\hline & s5 & .039 & .049 & .033 & .813 & .417 \\
\hline & s6 & .046 & .037 & .065 & 1.245 & .213 \\
\hline
\end{tabular}

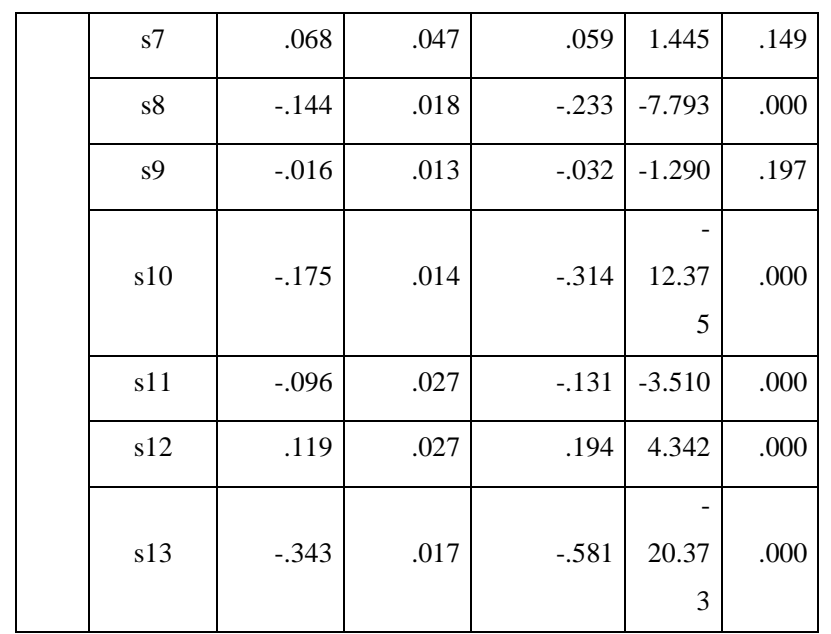

\section{Regression Equation:}

$Y_{\text {(performance) }}=S 1 X 1+S 2 X 2+S 3 X 3+S 4 X 4+S 5 X 5+S 6 X 6$ + S7X7 + S8X8+S9X9+S10X10+S11X11+S12X12+ $S 13 X 13+C$

Where:S1 - Inter-Role distance \& overloads, S2 - Job nature, S3 - Work -family conflict, S4 - Boredom induced stress \& health consequences, S5 - Role Ambiguity, S6 Resource Inadequacy, S7 - Time pressure, S8 - Role Expectation, S9 - Personal inadequacy, S10 - Recompense, S11 - Personal Stress, S12 - Uncertain support, S13 - Work load stress, C - Constant

\section{Interpretation:}

From the above table it is evident that Role Ambiguity, Resource Inadequacy, Time pressure, Personal inadequacy does not have a significant influence, because the calculated values are .417, .213 and .197 which are greater that the prescribed level of significance. On the other hand other factors like Inter-Role distance \& overloads, Job nature, Work -family conflict, Boredom induced stress \& health consequences, Role Expectation, Work load stress, Personal Stress, uncertain support and Recompense has an influence since the calculated values are less than that of the prescribed level of significance.

Table showing the impact of Job satisfaction of Medical Representatives on their Performance in kerala.

Table 1.2 - Impact Of Job Satisfaction Of Medical Representatives On Their Performance In Kerala ANOVA

\begin{tabular}{|c|c|c|c|c|c|c|}
\hline \multicolumn{2}{|c|}{ Model } & Sum of & Df & Mean & $\mathrm{F}$ & Sig. \\
\hline \multirow{3}{*}{1} & $\begin{array}{l}\text { Regress } \\
\text { ion }\end{array}$ & 321.390 & 6 & 53.565 & $\begin{array}{l}193.5 \\
33\end{array}$ & .000 \\
\hline & $\begin{array}{l}\text { Residua } \\
\text { l }\end{array}$ & 199.278 & 720 & .277 & & \\
\hline & Total & 520.669 & 726 & & & \\
\hline
\end{tabular}

a. Dependent Variable: ep

b. Predictors: (Constant), sat6, sat4, sat3, sat5, sat1, sat2

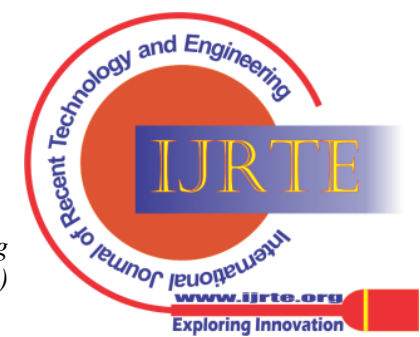




\begin{tabular}{|c|c|c|c|c|c|c|}
\hline \multicolumn{7}{|c|}{ COEFFICIENTS } \\
\hline & \multirow{2}{*}{ Model } & \multicolumn{2}{|c|}{$\begin{array}{l}\text { Unstandardized } \\
\text { Coefficients }\end{array}$} & \multirow{2}{*}{$\begin{array}{c}\text { Standardized } \\
\text { Coefficients }\end{array}$} & \multirow{2}{*}{$\mathrm{T}$} & \multirow{2}{*}{ Sig. } \\
\hline & & B & $\begin{array}{l}\text { Std. } \\
\text { Error }\end{array}$ & & & \\
\hline \multirow{7}{*}{1} & (Constant) & 0.953 & 0.068 & & 14.056 & 0 \\
\hline & sat1 & 0.132 & 0.018 & 0.254 & 7.268 & 0 \\
\hline & sat2 & 0.161 & 0.025 & 0.229 & 6.549 & 0 \\
\hline & sat3 & 0.181 & 0.019 & 0.293 & 9.38 & 0 \\
\hline & sat4 & 0.111 & 0.016 & 0.2 & 6.888 & 0 \\
\hline & sat5 & 0.083 & 0.017 & 0.156 & 4.818 & 0 \\
\hline & sat6 & 0.034 & 0.028 & 0.036 & 1.206 & 0.228 \\
\hline
\end{tabular}

Regression Equation:
$Y_{\text {(performance) }}=0.132_{x 1}+0.161_{x 2}+0.181_{x 3}+0.111_{x 4}+$ $0.083_{x 5}+0.034_{x 6}+C$

Sat1 - Pressure on the job, Sat2 - Supervision, Sat3 Orientation and Training, Sat4 - Compensation and benefits, Sat5 - Supportive work condition, Sat6 - Employee recognition,

$$
\text { C - Constant }
$$

\section{Interpretation:}

From the above table it is evident that Employee recognition does not have a significant influence, because the calculated value is .228 which is greater that the prescribed level of significance. On the other hand other factors like Pressure on the job, Supervision, Orientation and Training, Compensation and benefits, Supportive work condition has an influence since the calculated values are less than that of the prescribed level of significance.

\section{1-Diagram Showing The Consequences Of Job Stress}

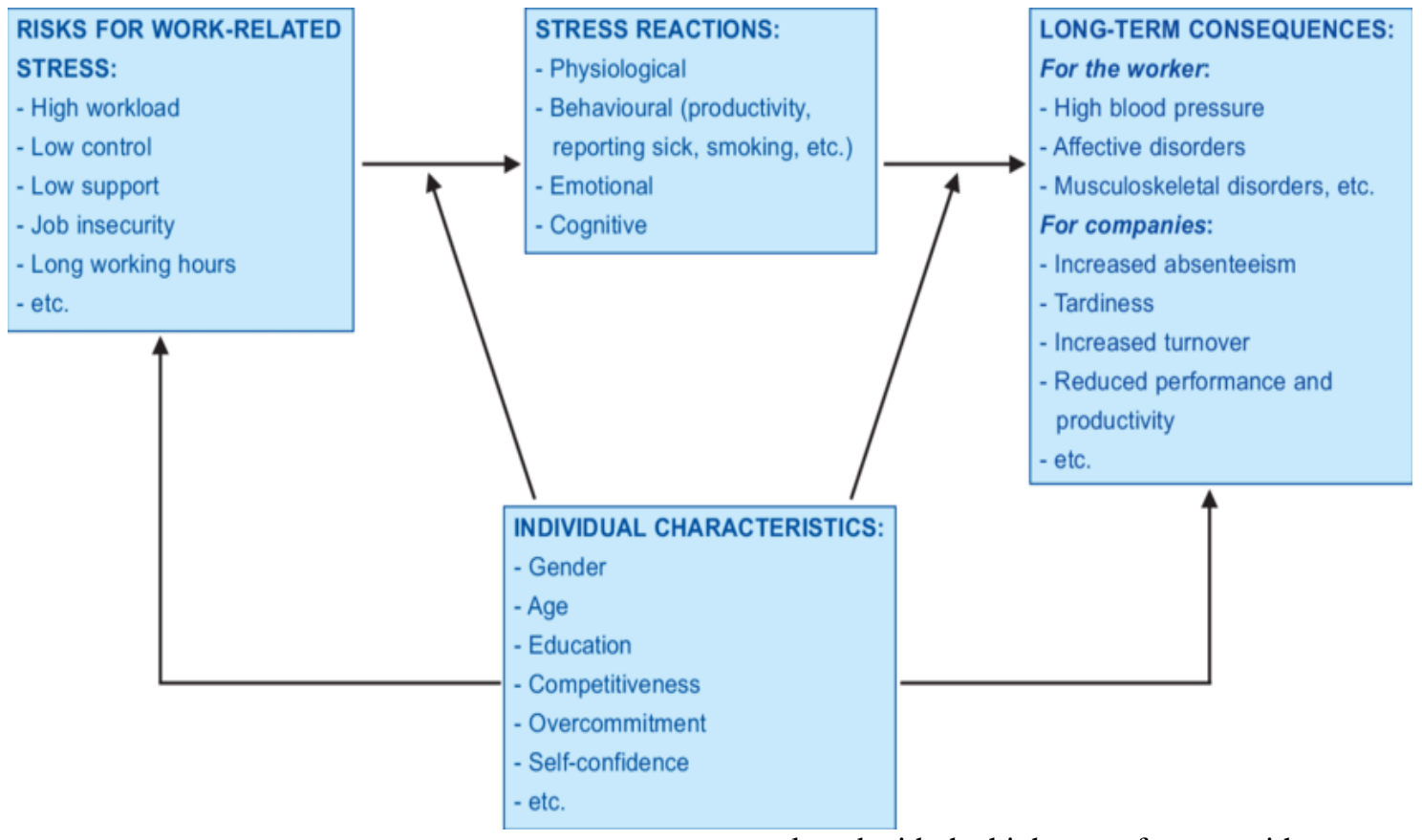

\section{VII.FINDINGS}

The study "Stress and Job Satisfaction Towards Performance of Medical Representatives at Central Kerala" was conducted and a detailed findings of the survey are are put forth with variables like gender, age, marital status, year of experience, religion, place of birth, education qualification, monthly salary, firm type and management level. As far as gender is concerned Male employees are higher than the Female employees, whereas the frequencies of the male employees range up to 536 and female employees up to 191. When age group is considered, the people aged between 25 to 35 are employed more into the field of medical representatives with an average number of 271 amongst the 727, followed by the people aged between 25 to 35 with an average of 234, people aged between 46 to 55 with an average of 154 whereas people above 55 are the least involved in this Job with an average of 7 amongst 727. This shows the most and least people involved into this particular field of work. Marital status do play a vital role, the survey depicts that the people who are married are

employed with the highest preference with a range of around 596 people and the unmarried / single are less into the field of Medical professionals comparatively. Religion do have an impact on the work, people who belong to Hindu religion are the highest in number which ranges around 432, people from Muslims category are the least to join with a count of around 142 and the Christians around 153. Place of birth of the employees is also considered to be an important aspect. The people from urban area are most involved with a count of 281 and people from the Rural area constitutes around 238 and the least involved are the employees from the semi urban part as their number falls around 208. The type of company also matters when job is considered and here the survey shows that the Indian-based companies are more with an average of 434 whereas the Foreign based firm constitute the lesser with that of 293 firms.

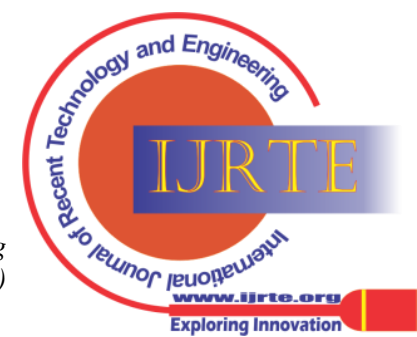


Factors Affecting Stress and Job Satisfaction its Impact on Performance of Medical Representatives at
Central Kerala Region with Special Reference to Era of Coronavirus (COVID-19) -Pandemic Outbreak.

\section{VIII.DISCUSSION AND SUGGESTION}

Medical Representatives are subject to continuous Stress on account of targets and planned deadlines. The. Practicing Meditation, Yoga, Therapy and counselling can be incorporated to reduce work related Stress. An actionlearning based program is another way of motivating employee competencies Pharmaceutical companies can enhance this type of training programme. Policies regarding their travelling can be framed as they have to travel a lot which increase the accidental risk while travelling. Medical Representatives should concentrate on Personal development that will be of utmost use for him in his career.

\section{IX.CONCLUSION}

Stress is an inevitable part of one's life. The job stress may always affect the working nature of their profession. As current research indicates that employees are energised and motivated by moderate amount of stress. As far as mankind exists in this world, stress will also exist. It is born with him and also dies with him. Hence the chances of eradicating this problem, stress is never possible. But there are variety of ways to minimize or at least learn to live with stress without being much affected by its negative impact.

\section{REFERENCES}

1. McEwen B. Stressed or stressed out: what is the difference? J Psychiatry Neurosci. 2005;30:315-8

2. Michie S. Causes and management of stress at work. Occup Environ Med. 2002;59:67-72

3. U.S. Department of Health and Human Services. Stress at work. Cincinnati, Ohio: NIOSH publication;1999

4. Michie S. Causes and management of stress at work. Occup Environ Med. 2002;59:67-72.

5. Agarwal, R. (2001). Stress in Life and at Work. First Edition, Sage Publication: New Delhi.

6. Ahsan, N., Abdullah, Z., Fie, D. Y. G., \& Alam, S. S. (2009). A study of job stress on job satisfaction among university staff in Malaysia: Empirical study. European journal of social sciences, 8(1), 121-131.

7. Allan Brett, Wayne Burr, Jamaluddin Moloo, "Are Gifts from Pharmaceutical Companies Ethically Problematic?" Arch Intern Med, Vol. 163, Oct 2003.

8. Anita Odigie (2016) Stress Management for Health Care Professionals, Human Ageing and Elderly Services.

9. Armstrong M. (2001) A Handbook Of Human Resource Management, Great Britan: Kogan.

10. Aspridis, G., (2013). Alternative ways of motivating employees during the economic crisis. The impact of the music on increasing the employee's efficiency. Proceedings of the National Conference of Economics and Management 2013, Larissa, 8-10/6/2013

11. Aswathappa K. (2015) Human Resource and Personnel Management - Text And Cases, New Delhi: Tata Mc Graw Hill, Pp 390-396

Websites: -

1. www.google.com

2. www.researchgate.com

\section{AUTHORS PROFILE}

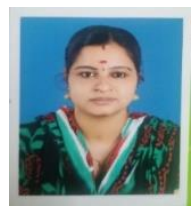

Gayathri. T.J,graduated, in Bachelor of Business Administration(BBA),Post graduation in Master of Business Administration(MBA),M.Phil Management from Bharathiar University. Currently pursuing Ph.D in Management., Nehru College of Management, Bharathiar university. Published papers in various disciplines of Management. Some publications and research works:- "A Comparative Study on Work- life Balance with Satisfaction level and its impact on performance of Medical Representatives of south kerala"in the standard refereed / SCI journal name International Journal Of Research And Analytical Reviews with Vol.No.7, issue-2, page Nos 892-900 and year of publication April 2020 "EXAMINING THE STRESS LEVEL OF PHARMACEUTICAL COMPANY REPRESENTATIVES AND ITS INFLUENCE TO JOB SATISFACTION AND PERFORMANCE." in the standard refereed / SCI journal name International Journal Of Creative Research Thoughts with Vol.No.8, Issue-7,page Nos4434-4441 and year of publication July2020. EMPLOYEE EMPOWERMENT AND ITS IMPACT ON JOB SATISFACTION AMONG DOCTORS 2018 IJRAR December 2018, Volume 5, Issue 4 www.ijrar.org (E-ISSN 2348-1269, P- ISSN 2349-5138) IJRAR1944545 International Journal of Research and Analytical Reviews (IJRAR) www.ijrar.org 193

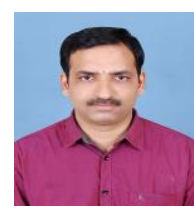

Dr. Easwaran Muthukumar, is an alumnus of SNR Sons college (Autonomous), Coimbatore. He holds five post graduates degrees in Business Administration, Commerce, Finance \& Control, labour Management and Psychology. Besides his brief corporate exposure, he has about 17 years of experience in teaching and research. He organised and participated in several Seminars, workshops and Management developement Programmes in the area of Financial Services, Capital Market, Risk Management, Derivatives \& FOREX and actively involved in consultancy assignments. He has to his credit 56 notable research papers and articles in reputed National and International Journals \& magazines. His meticulous research work on Advancement of Banking Technology got him awarded the PhD degree in Management and also guiding scholars both Ph.D and M.Phil degrees, awarded 6 Ph.D \& 6 M.Phil scholars in Management subject. Currently, he is serving Professor in MBA, Nehru College of management, Coimbatore.

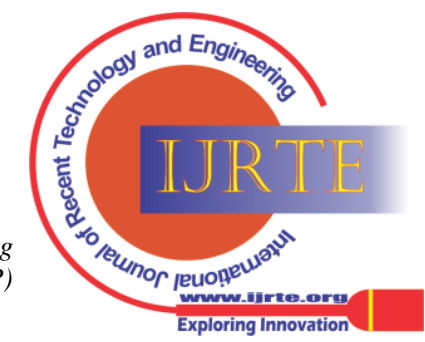

